\title{
Market-Induced Fiscal Discipline in Europe
}

\author{
Gianluca Cafiso $^{1}$ (D) $\cdot$ Roberto Cellini $^{1}$
}

Received: 2 October 2020 / Accepted: 23 December 2021 / Published online: 7 March 2022

(c) The Author(s) 2022, corrected publication 2022

\begin{abstract}
We discuss and test market-induced fiscal discipline, with an emphasis on the conditions that determine its emergence. The analysis is based on the effect of the public-debt interest bill on key budget variables in the European Union over the 1995-2019 period. We focus on conditions regarding threshold effects, institutional characteristics and the government's political orientation. We assess also whether fiscal discipline, which we detect on average, emerges constantly over the entire period. Overall, a positive robust effect from interest payments to the primary budget emerges, such an effect materializes mainly through expenditure containment and it results to depend significantly on some of the conditions tested.
\end{abstract}

Keywords Primary budget · Interest bill $\cdot$ Public debt · Fiscal discipline $\cdot$ Europe

JEL Classification H61 $\cdot$ H62 $\cdot$ H63 $\cdot$ E62 $\cdot$ E63

\section{Introduction}

Public debt has been back in the limelight since the Global Financial Crisis. Even though there has been nothing specifically new with public debt itself, whenever its sustainability goes under strain, it becomes a serious concern for policymakers and the public. As matter of fact, even when it is sustainable, public debt may be a burden, conditions budget policy and undermines economic growth (Barro 1990). ${ }^{1}$ Such a burden is quantified by the interest bill in GDP terms. It is observed, however, that public debt is not a major concern in all countries with high debt-to-GDP ratios. Some

\footnotetext{
${ }^{1}$ Insightful reviews about this topic are in Panizza and Presbitero $(2013,2014)$.

Gianluca Cafiso

gianluca.cafiso@unict.it

https://www.dei.unict.it/docenti/gianluca.cafiso

Roberto Cellini

roberto.cellini@unict.it

https://www.dei.unict.it/docenti/roberto.cellini

1 Dipartimento di Economia e Impresa, Università degli Studi di Catania, Corso Italia 55, Catania, Italy
} 
of those take fiscal decisions that do not reflect the need to contain public debt, while some others are seriously committed to debt reduction or, at least, make an effort to appear committed. In the recent past, debt-motivated fiscal consolidations-based on expenditure, tax or both-are believed to have had deep consequences both in terms of economic development (Alesina and Ardagna, 2010), social cohesion (Agnello and Sousa 2014; Agnello et al. 2016, 2017) and trust in the EU integration dogma.

As for the future, the pandemic outbreak in 2020 has reinforced the increasing trend of public debt and this poses new challenges. Indeed, even though no western government is currently engaged in fiscal consolidations, probably thanks to central banks' interventions, some expect a time when things will be back to normal and there will be need to act to rebalance towards a more sustainable fiscal stance (Brunet and Pàrraga 2021). Coherently, we believe that the topic object of this work is likely to be again an important part of the political debate at some point in the next years.

The objective of our research is to verify whether the interest bill influences budget policy, this is the so-called market-induced fiscal discipline hypothesis (Heinemann and Winschel 2001; Tkačevs and Vilerts 2019), and to test some conditions that might drive that effect. We study conditions related to threshold effects, institutional characteristics and political orientation, we also check the temporal evolution of market-induced fiscal discipline in Europe as a consequence of the different crises and policy interventions over the last two decades.

We develop our empirical analysis using almost the full sample of European Union countries over the 1995-2019 period. Our research proves that market-induced fiscal discipline emerges and it materializes more on the expenditure side of the budget, it became stronger after the Global Financial Crisis, and that threshold effects are significant. Furthermore, political orientation and fragmentation drive to some extent fiscal discipline. The paper is structured as follows. Section 2 explains the motivations at the basis of our research and reports on some relevant literature. Some problems intrinsic to the study of market-induced fiscal discipline in the EU are detailed in Sect. 3. Section 4 outlines our analysis and discusses the conditions for market discipline. The regression analysis about the effect of the interest bill on the primary budget and the significance of the conditions is in Sect. 5. Section 6 draws the conclusions.

\section{Conceptual Framework and Related Literature}

\subsection{Conceptual Framework}

Financial integration in Europe has been an ongoing process for the last three decades. The Maastricht Treaty signed in February 1992, which defined the stages and criteria of the Economic and Monetary Union, is probably the most significant act of the whole project. Financial integration is generally regarded as an achievement functional to Europe's economic development. Nonetheless, some economists argue that it may have also paved the way to the euro-area debt crisis in 2011-2012 (Korner and Zemanek 2013). They hypothesise that financial integration allowed periphery EU countries to enjoy unrealistically low interest rates thanks to a favourable credibility shock (see Fig. 4 in the appendix): they benefited from having bounded their future closer to the 
budget-responsible core EU countries (Caporin et al. 2018). ${ }^{2}$ As a drawback, such lower rates allowed them to increase their expenditure and grow in debt (public and private) up to a level at which they became vulnerable to adverse shocks, such as the sudden stop in 2011.

When interest rates increased because of rapidly deteriorating confidence (Cafiso 2016), the impact on the now larger amount of debt was unsustainable in the medium term. This motivated a reduction of public expenditure (the so-called austerity) in the effort to counterbalance the interest bill, to achieve a smaller deficit, and to show commitment to a sounder fiscal stance to financial markets. Based on this account, financial markets induced fiscal corrections in many countries. A dynamic of this kind is not exclusive to the euro-area debt crisis. Indeed, it has been the object of economic research much earlier in time (Bishop et al. 1989).

Reporting on some previous literature (Bishop et al. 1989; Bayoumi et al. 1995), both De Haan and Sturm (2000) and Heinemann and Winschel (2001) spell out the requirements for markets to be able to exert such a corrective pressure. Under the assumptions of absence of bailout provisions, independence of the central bank and of a stable financial system, the requirements are: first, markets need to be sensitive to the fiscal stance and full information is available (reaction of the risk premium to an increasing sovereign risk); second, borrowers have to be responsive to and react to an increase of the risk premium. Research has proved that the first requirement is often met, differently, the second is less certain. In fact, as De Haan and Sturm (2000) suggest as a possibility across many, even if governments face higher borrowing costs they might continue borrowing to increase their chance for re-election. The object of our research relates to such a second requirement and to the conditions for which it is met. In the remainder of the paper, we refer to it as Market-Induced Fiscal Discipline (MIFD) to mark that it consists of the discretionary response of fiscal authorities to market pressure.

To contextualize our discussion, we highlight that the second requirement for MIFD is embedded in the debt-stabilization rule. Apart from GDP growth, which is not under Government control, the primary surplus is the key tool to stabilize the debt-to-GDP ratio (DGR): a primary surplus equal to the interest bill is to achieve stabilization. Let us assume that risk premia respond to the evolution of the DGR. To avoid increasing borrowing costs and an excessively unbalanced budget, the government reduces the deficit either through a cut of expenditure, a tax increase or a combination of the two. ${ }^{3}$ This is easily synthetized in the government's budget identity (Cafiso 2012):

$$
\underbrace{G_{t}+i_{t} B_{t-1}}_{\text {expenditures }}=\underbrace{T_{t}+\left(B_{t}-B_{t-1}\right)}_{\text {revenues }},
$$

where $G_{t}$ is public expenditure, $T_{t}$ is tax revenues, $i_{t}$ is the interest rate, $B_{t}$ is the outstanding public debt. Accordingly, $O B_{t}=T_{t}-G_{t}-i_{t} B_{t-1}$ is the Overall Budget

\footnotetext{
2 The process leading to the Euro introduction has been characterized by decreasing interest rates on public debt in many Euro Area countries (Cafiso 2016); see Fig. 4 in the appendix.

3 To bear in mind that different consolidation strategies have different effects on economic activity: Perotti (2013), Giordano et al. (2007), Romer and Romer (2010), Cafiso and Cellini (2014).
} 
and $P B_{t}=T_{t}-G_{t}$ is the Primary Budget. When $i_{t} B_{t-1}$ increases, $G_{t}$ must decrease to maintain the budget balanced or, symmetrically, $T_{t}$ needs to increase.

\subsection{Related Literature}

Since De Haan and Sturm (2000) and Heinemann and Winschel (2001), there have been several other insightful contributions on this topic. Among the others, Tkačevs and Vilerts (2019) estimate fiscal reaction functions to study the effect of government borrowing costs on cyclically-adjusted primary balances. Bamba et al. (2020) report on the effect of cuts to specific expenditure items and show that market-induced fiscal consolidations reduce significantly the government's investment to consumption ratio. They conclude that those fiscal consolidations may therefore be harmful in the long run because of such a detrimental composition effect. The same requirements for MIFD discussed above are in De Groot et al. (2015). Differently from other contributions, they test them simultaneously in a vector autoregression and conclude in favour of MIFD just when some concurrent further conditions are met; such as high debt-to-GDP ratio, low costs for changing the fiscal stance and presence of fiscal rules. Dell'Erba et al. (2015) focus on discretionary multiyear fiscal consolidations in OECD countries during the last three decades. They find that market pressure is not associated with this specific kind of consolidation strategy, suggesting that MIFD is less short-lived in nature. Of course, budget policy depends on many further inputs in any case, and not just on the interest-bill; among the others, see Hallerberg and Strauch (2002).

Fiscal consolidations have been object of investigation also in the political-economy literature for a long time (Alesina and Roubini 1992; Hicks and Swank 1992). Contributions in this literature do not focus specifically on market-induced consolidations but on consolidations in general, nonetheless, the same provide useful insights. Potrafke (2017) makes a consistent review of this literature and suggests that party cohesion, as well as traditional right-left contraposition, has changed a lot in the last two decades with subsequent variations on consolidation policies. Mierau et al. (2007) affirm that political variables are not that important for fiscal consolidations, finding relevance just for economic variables and that the likelihood of fiscal consolidations is influenced by the date of elections. In an opposite direction, Armingeon et al. (2016) show that during budget consolidations implemented by left-wing broad coalition governments, welfare state retrenchment is greatest. Hübscher (2016) distinguishes between consolidation events and consolidation size, he concludes that both right and left are likely to implement cuts but right cuts more than strictly necessary and that those cuts are more likely at the beginning of the legislative term. Potrafke (2020) provides interesting insights on the composition of expenditure (by activity) at the general and central level of government showing that political orientation matters. All this said to highlight the importance of testing for political orientation in consolidation strategies.

In the Sect. 4, we detail our analysis and its contribution in this context. 


\section{Caveats for the Study of MIFD in the EU}

As for the context in which MIFD might have taken place in the EU over the last decades, there are some important features to point out.

Budget rules are an intrinsic characteristic of the European Union, more correctly, of the Economic and Monetary Union, which is the essence itself of the European Union. Indeed, all the countries in the European Union, and not just those having the Euro as a currency, are bounded to the Stability and Growth Pact. ${ }^{4}$ As matter of fact, the set of rules has evolved significantly since 1992, the time when the Maastricht Treaty came into force. Following the European Fiscal Board's dataset on fiscal rules compliance (Larch and Santacroce 2020), fiscal rules currently operative in the EU can be classified as: (1) Deficit rules, valid since 1992; (2) Debt rules, valid since 1992; (3) Structural Balanced Budget rules, valid since 2005; (4) Expenditure rules, valid since 2012. The amount of compliance with such rules is disputable (Larch and Santacroce 2020) and there have been reforms of the rules along the way, alternatively to loosen or tighten them.

The decision to consolidate the budget might theoretically be in response to market pressure coherently with the MIFD hypothesis, but also because of institutional budget rules that require to maintain the budget balanced. ${ }^{5}$ We will control for this at different points in our analysis. First, by distinguishing between EU and non-EU countries based on the different accession dates. Secondly, by means of threshold estimations that control for the effect of our variable of interest at different level of market pressure. We explain also why our results catch MIFD and not compliance to budget rules in the "Discussion of the results" section.

Another important aspect concerns monetary policy. In fact, it is able to annul the corrective pressure exerted by markets, either directly or indirectly. As for conventional monetary policy, an interest rate reduction could reduce the cost of the debt rollover to a point that the interest bill stabilizes. Then, no need for consolidation might be in the end. As for unconventional monetary policy, to wit quantitative easing, it acts directly against market pressure by increasing prices and lowering yields. The ECB response to the Great Recession, to the euro-area debt crisis and to the pandemic are examples of expansive monetary policies with this kind of positive effects. ${ }^{6}$ Accordingly, we will evaluate whether the common monetary policy has altered the need for MIFD in the EU.

In conclusion, events such as the Global Financial Crisis in 2007/08 and the Great Recession in 2009, the 1st wave of the Euro Debt crisis in the first half of 2010 (involving Greece, Portugal and Ireland), the 2nd wave of the Euro Debt crisis in the

\footnotetext{
${ }^{4}$ Budget monitoring and fiscal coordination for the countries that have accessed Stage III of the Economic and Monetary Union, alias have adopted the Euro, is somehow stronger and more intrusive. Nonetheless, the same set of rules applies both to non-euro area and euro area countries; the rationale is that those rules are functional to the single European market, not just to the monetary union.

5 Furthermore, voters' attitude towards the budget stance can play a role; that is, citizens might disapprove an excessively loose budget policy.

6 Since the July 2012 ECB President Draghi's "whatever it takes" speech, interest rates have been kept low to ensure financial stability and member states' ability to manage their debt. The several quantitative-easing programmes launched during the following years have reiterated the effect and communicated to markets the ECB's willingness to stick to that objective.
} 
second half of 2011 (involving Italy and Spain), as well as the ECB interventions in response to such crises might have altered significantly each country's commitment to fiscal discipline. To check this possibility, we will study the temporal evolution of MIFD.

\section{Outline of the Analysis}

With respect to the literature discussed in the previous Sect. 2, the scope of our research is to verify whether MIFD emerges and to check some specific conditions on which it might depend. We start by searching for MIFD in the group of EU27 countries, also with the intent to unveil on which side of the budget it is more likely to materialize.

After that, we study at which extent MIFD depends on the current level of the DGR and of the market yield. In fact, apart from the variation of the interest bill, MIFD likely kicks in when market pressure and sentiment are adverse, and countries are more vulnerable. Countries with a high DGR are indeed more vulnerable to market pressure because of their larger refinancing needs. This is why those might be keener on MIFD. At the same time, even countries with a low DGR might end to consolidate the budget when they observe their borrowing costs to increase remarkably.

As mentioned in Sect. 3, MIFD is likely to have undergone different phases in terms of commitment, those mainly determined by the crises occurred (the global financial crisis and the European debt crisis). ${ }^{7}$ In this regard, we test whether structural breaks are detectable and whether MIFD is constant along the period considered.

In the remainder, we investigate some political-economy aspects, whose potential relevance the literature on fiscal consolidations has suggested. We start by verifying whether MIFD depends in terms of timing on the electoral cycle. Secondly, we consider the results of the elections in terms of parliamentary fragmentation with the intent to verify whether fragmentation undermines MIFD. With the same scope, we consider also the strength of the executive in terms of parliamentary majority. Eventually, we investigate whether the political ideology of the incumbent government plays a role. Indeed, different political parties might respond differently to market pressure on an ideological ground.

\subsection{Analytical Approach}

Our analytical approach consists on estimating the effect of the interest bill in year $t\left(I B L_{t}\right)$, along with other explanatory variables, on the cyclically-adjusted primary balance in year $t+1\left(P B T_{t+1}\right) .^{8}$ The assumption is that the government observes

\footnotetext{
7 Both crises have caused serious swings in terms of budget stance. Furthermore, particularly the latter crisis, after the stepping in of the ECB in an outspoken defence of the Euro, might have determined a different phase (a structural break) regarding European countries' commitment to MIFD.

8 The primary balance is the net between total revenues and primary expenditures; the latter being the amount of money spent by the general government for goods and services and not to pay interests on public debt. The cyclical adjustment is done by the EU Commission with respect to Potential GDP. We try also variables adjusted with respect to Trend GDP for robustness. For more information on cyclical adjustment, see Fedelino et al. (2009).
} 
the variables in year $t$ and decides about the year $t+1$ budget. This time setting is central to our strategy and reflects the fact that the year $t+1$ budget is defined through the budget law approved in year $t$; Presbitero et al. (2014) is an example using a similar time setting across budget variables. The need to consider discretionary adjustments reflects into the use of cyclically-adjusted variables, which correct for the business cycle (alias the deviation between potential and actual GDP). To notice that in this setting regressors are predetermined with respect to the dependent variable, this ensures their exogeneity.

The analysis is developed in terms of first differences. Even though modelling growth rates is a harder task than modelling levels, this generally reflects in a much lower regression fit, our focus is on discretionary variations of the fiscal stance. Moreover, first differences help to reduce the autocorrelation of the series. ${ }^{9}$ In conclusion, the analysis is therefore developed through the following regression:

$$
Y_{i, t+1}=\beta_{0, i}+\beta_{1} \cdot \mathrm{X} 1_{i, t}+\sum_{m=2}^{M} \beta_{m} \cdot \mathrm{X} m_{i, t}+\varepsilon_{i, t}
$$

$\mathrm{Y}$ is the next-year variation of the primary budget $\left(\Delta \mathrm{PBT}_{i, t+1}\right), \mathrm{X} 1$ is the current variation of the interest bill $\left(\Delta I B L_{i, t}\right)$, the other M-1 variables are further explicatives also in first difference. $\beta_{1}$ returns the effect of the interest bill. It should be signed positive when the dependent variable is the primary budget if MIFD occurs: a positive variation of the interest bill causes an improvement of the primary budget.

The remaining set of M-1 control variables is selected trough a vast review of the literature. ${ }^{10}$ The list of explicatives includes: the unemployment rate, to account for pressure on expenditure related to unemployed workers as well as for the business cycle; the real effective exchange rate, to account for the cost variation of goods and services purchased abroad as well as for the performance of the economy related to its external relations; the current account, to reflect another dimension of the economic stance; the share of workers aged 25-49 over the total, this should reflect the number of people who participate more actively to the economy; the inflation rate to account for price dynamics. ${ }^{11}$ A summary list of all the variables and their source is in Table 1 in the next subsection (Data).

$\beta_{0, i}$ are the country-specific fixed effects that should capture all the time-invariant characteristics of each country. In a robustness check of our baseline estimations, we have included also time dummies to account for common time developments. As it emerges from the comparison of Table 3 against Table 8, the estimation output remains unchanged. We therefore opted not to include time dummies on the basis of parsimony considerations.

\footnotetext{
9 This allows us to avoid inserting the lagged dependent variable into the panel regression and to use the more flexible standard fixed-effect estimator, which serves better the scope of our research.

10 Tkačevs and Vilerts (2019), Bamba et al. (2020), De Groot et al. (2015), Dell'Erba et al. (2015), Potrafke (2020), Bojar (2019), Hübscher (2016), Heinemann and Winschel (2001). Given the large spectrum of fields in which the public sector intervenes, general macroeconomic variables are commonly used as explicatives.

11 Since the dependent variable and the interest bill are both in GDP terms, we do not include the GDP.
} 
Table 1 List of variables

\begin{tabular}{|c|c|c|c|}
\hline Variable & Acronym & Source & Unit \\
\hline \multicolumn{4}{|l|}{ Dependent variables } \\
\hline C.A. Primary budget & PBT & Ameco & GDP $\%$ \\
\hline C.A. Primary public expenditures & PPE & Ameco & GDP $\%$ \\
\hline C.A. Total public revenues & TPR & Ameco & GDP $\%$ \\
\hline \multicolumn{4}{|l|}{ Regressors } \\
\hline Interest bill & IBL & Ameco & GDP $\%$ \\
\hline Unemployment rate & UNR & Eurostat & Share of labour force \\
\hline Consumer price index & CPI & Eurostat & Index \\
\hline Real effective exchange rate & RER & Eurostat & Index \\
\hline Current account & $\mathrm{CAC}$ & Eurostat & GDP $\%$ \\
\hline Share of population $25-49$ & PPS & CPDS & Share of active workers \\
\hline Real gross domestic product & GDP & Ameco & Index \\
\hline \multicolumn{4}{|c|}{ Variables used to check the conditions on MIFD } \\
\hline Debt-to-GDP ratio & DGR & Ameco & GDP $\%$ \\
\hline 10-year Gov. bond yield & GBY & Eurostat & $\%$ \\
\hline EA membership, dummy & EAd & constructed & $0 / 1$ \\
\hline EU membership, dummy & EUd & constructed & $0 / 1$ \\
\hline General election dummy & ELEd & CPDS & $0 / 1$ \\
\hline Fragmented political system, dummy & FPSd & CPDS & $0 / 1$ \\
\hline Strongly supported executive, dummy & SSEd & CPDS & $0 / 1$ \\
\hline Party predominance at Gov, control & PPGc & CPDS & $1-2-3-4-5$ \\
\hline
\end{tabular}

CPDS stands for Comparative Politics Data set (Armingeon et al. 2020)

Our objective is to test some specific conditions that might determine MIFD. We test those conditions through non-linear estimates of $\beta_{1}$. Such non-linear estimates are delivered in two ways: first, using interactions between the interest bill and dummy/categorical variables, secondly, through threshold estimations à la Hansen (1999). The former tests for non-quantitative conditions, the latter for quantitative conditions.

\subsection{Data}

Our data sample consists of yearly data for 27 European Union countries over the period 1995-2019, all EU countries but Croatia (UK included). We refer to such a data sample as EU27. ${ }^{12}$ The list of variables used for the estimation of Eq. 2 is reported in Table 1 along with its source. ${ }^{13}$

\footnotetext{
12 Data for Croatia are almost always missing before 2000. We need a balanced panel, we therefore rule it out and use the remaining 27 EU countries.

13 We employ budget data for the General Government entity, which is constituted by the Central Government, State Governments, Local Governments and public Social Security Funds. Bartolini et al. (2017)
} 


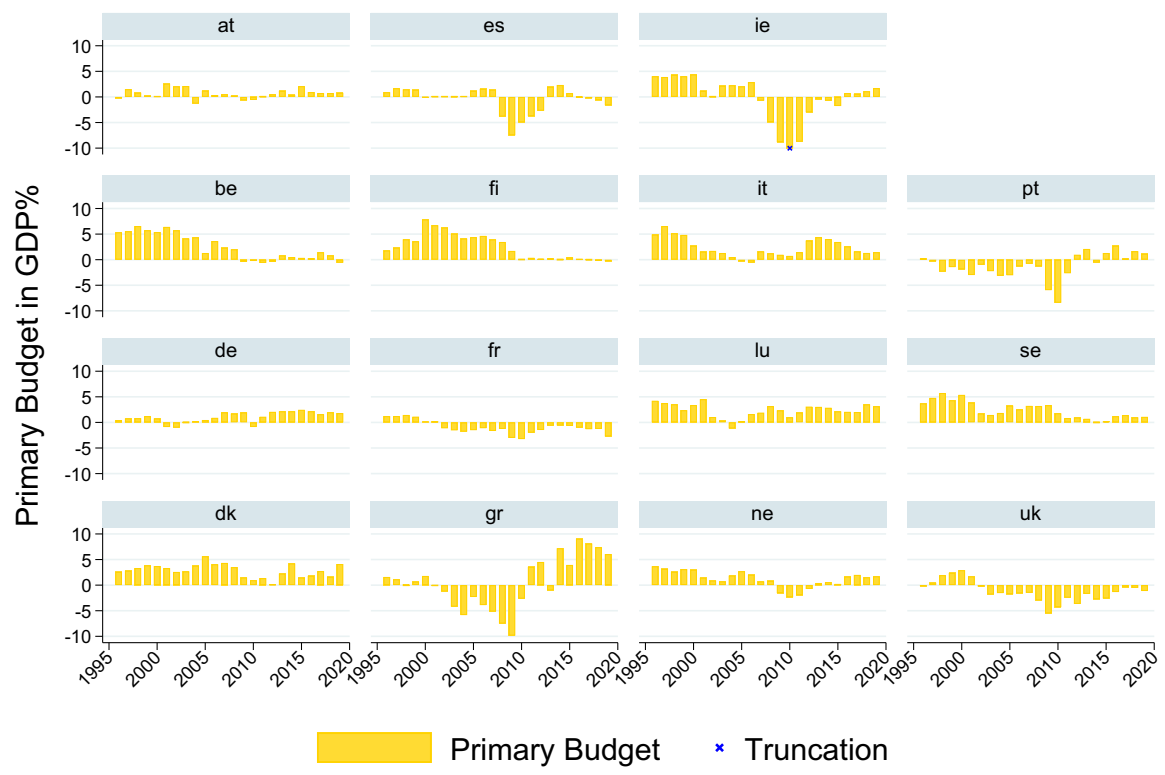

Fig. 1 Primary Budget, EU15 group

We plot in Figs. 1 and 2 respectively the primary budget and the interest bill for the subgroup of EU15 countries for visual inspection; the EU15 group is made of the fifteen EU countries before the 2004 enlargement. The same are in Figs. 5 and 6 in the appendix for the non-EU15 countries.

The dynamics of the interest bill from Fig. 2 (and Fig. 6 in the appendix) is really decreasing in all countries until 2007, and for some others all along the period considered. The evolution of the primary budget in GDP terms in Fig. 1 (and Fig. 5 in the appendix) is less homogeneous across countries. Nevertheless, southern-European countries such as Greece, Italy and Portugal exhibit a deteriorating primary budget after the launch of the Euro that contrasts with the clearly downward trend of their interest bill.

For the discussion we develop in the following sections, we report some correlations of interest in Table 2.

As for the variables to check the conditions on MIFD, the quantitative conditions use the debt-to-GDP ratio and the market yield of the benchmark 10-year government bond. The non-quantitative conditions are tested using dummy/categorical variables based on variables extracted from the Comparative Politics Data Set (Armingeon et al. 2020). The non-quantitative conditions we test are: EU membership, euro-area membership, time breaks, closeness to general elections, fragmentation of the political spectrum, strength of the incumbent government and the political ideology of the incumbent government (left/centre/right).

Footnote 13 continued

explain that considering all the government levels is necessary when studying budget policy since an expenditure structure fragmented across different levels of government may influence the consolidation outcome. 


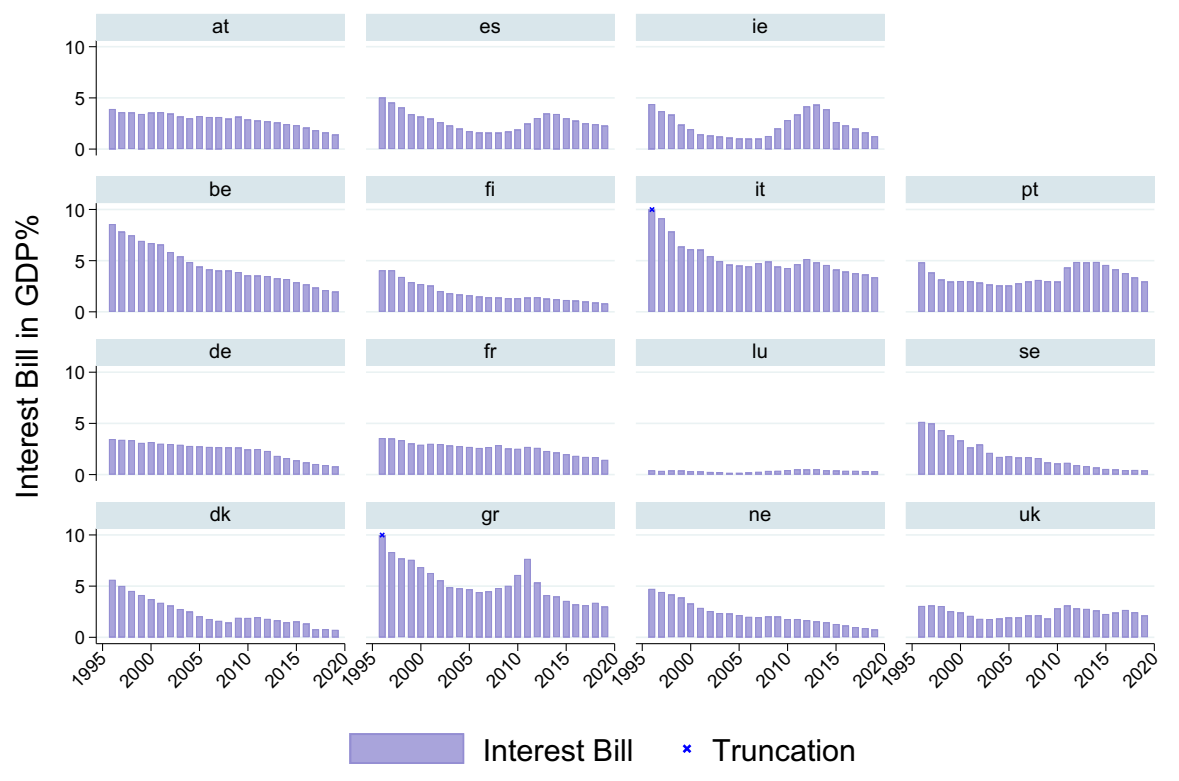

Fig. 2 Interest Bill in GDP\%, EU15 group

Table 2 Correlations

\begin{tabular}{llllll}
\hline Variables & (1) $\Delta . \mathrm{IBL}$ & (2) $\Delta . \mathrm{DGR}$ & (3) $\Delta . \mathrm{PBT}$ & (4) $\Delta . \mathrm{PBT}^{*}$ & (5) $\Delta . \mathrm{GBY}$ \\
\hline (1) $\Delta . \mathrm{IBL}$ & 1.000 & & & & \\
(2) $\Delta . \mathrm{DGR}$ & 0.568 & 1.000 & & & \\
(3) $\Delta . \mathrm{PBT}$ & 0.056 & -0.197 & 1.000 & & \\
(4) $\Delta . \mathrm{PBT} *$ & 0.182 & 0.037 & 0.897 & 1.000 & \\
(5) $\Delta . \mathrm{GBY}$ & 0.286 & 0.116 & -0.045 & 0.058 & 1.000 \\
\hline
\end{tabular}

IBL is the interest bill in GDP terms, DGR is the debt-to-GDP ratio, PBT is the cyclically-adjusted primary balance, $\mathrm{PBT}^{*}$ is the not cyclically-adjusted primary balance, GBY is the government bond yield

The Fragmented Political System dummy (FPSd) is based on the index of legislative fractionalization. It equals 1 for index values below the 25 th percentile; the index ranges between 0 (minimal fractionalization) and 1 (maximal fractionalization). Fractionalization is in terms of the number of parties present in parliament. The strongly-supported executive dummy (SSEd) is based on the seat share in parliament of all parties supporting the government; such value ranges between 0 and $81.8 \%$. We set a threshold equal to the 75 th percentile, then the dummy is 1 for values above $59.1 \%$ and this captures governments with a large parliamentary majority. The categorical variable for ideology predominance at the government (PPGc) takes five values: 1 for hegemony of right-wing (and centre) parties (share of left parties at gov $=0$ ), 2 for dominance of right-wing (and centre) parties $(0<$ share of left parties at gov $<=$ 
33.33), 3 for balance of power between left and right $(33.33<$ share of left parties at gov < 66.67), 4 for dominance of social-democratic and other left parties $(66.67<=$ share of left parties at gov < 100), 5 for hegemony of social-democratic and other left parties (share of left parties at gov $=100$ ). For more info see (Armingeon et al. 2020).

\section{Results on Market-Induced Fiscal Discipline}

\subsection{Baseline Results}

Table 3 reports the estimation output of Eq. 2 when using the cyclically-adjusted primary budget, primary expenditures and total revenues as dependent variable in turn (Panel A). The estimation output in Table 3 shows that MIFD emerges neatly at the EU aggregate level, and it materializes mainly on the expenditure side. After having the information about the side of the budget on which consolidations mainly take place, we focus on the primary budget in the remainder of the analysis.

As for the other regressors, they do not contribute to the explanation of the dependent variable, which is meant to represent a discretionary change of the fiscal stance. This depends on several factors. ${ }^{14}$ Such macroeconomic variables are included just as a control in any case, their contribution is not relevant for the scope of our analysis.

The estimations in Panel B interact the interest bill with time-varying dummies, those account respectively for membership in the EU and in the EA. The EU dummy aims to control for budget rules in the EU by exploiting the different accession date of EU countries. The EA dummy aims to control for common monetary policy on MIFD. Both nicely support the fact that membership implies stronger MIFD, but MIFD emerges significantly even when countries are not yet member of the EU or of the EA. Then, to the extent that EU formal membership captures the presence of budget rules, this result is supportive of the fact that MIFD is not bounded to budget rules. ${ }^{15}$ We will get back to this point further on.

Starting from such a first evidence on MIFD, which shows significant different intensities across groups, we investigate other conditions that might drive the result about MIFD in what follows. Our investigation develops into the search of threshold effects (quantitative conditions), and into the evaluation of some non-quantitative conditions. Furthermore, we will investigate also the temporal evolution of MIFD.

\subsubsection{Robustness of the Estimations}

Table 7 in the appendix reports the same estimations in Panel A in which we have replaced the dependent variable. Columns 4-6 use budget variables cyclically-adjusted

\footnotetext{
14 Firstly, the use of variables in first difference with a different timing across the dependent and the independent variables. Secondly, the inclusion of fixed effects is likely to capture the effect of those variables to some extent. Thirdly, cyclically-adjusted variables are cleared of the effect of the business cycle, they therefore lose connection to the other macroeconomic variables.

15 The process of joining the EU requires to achieve specific convergence targets (Copenhagen criteria). This implies that even before formal accession to the Union, countries are bounded to rules to some extent. The formal accession date therefore is not a perfect cut-off point as for the analysis of the impact of budget rules in the EU, but it has undoubtedly some informative power.
} 
Table 3 MIFD estimations: baseline

\begin{tabular}{|c|c|c|c|c|c|}
\hline \multirow[t]{3}{*}{ Dep. variable } & \multicolumn{3}{|l|}{ Panel A } & \multicolumn{2}{|l|}{ Panel B } \\
\hline & (1) & (2) & (3) & (4) & (5) \\
\hline & $\Delta \mathrm{PBT}_{t+1}$ & $\Delta \mathrm{PPE}_{t+1}$ & $\Delta \mathrm{TPR}_{t+1}$ & $\Delta \mathrm{PBT}_{t+1}$ & $\Delta \mathrm{PBT}_{t+1}$ \\
\hline \multirow[t]{2}{*}{$\Delta \mathrm{IBL}_{\mathrm{t}}$} & $0.560 * *$ & $-0.428 * *$ & 0.132 & & \\
\hline & $(0.158)$ & $(0.131)$ & $(0.145)$ & & \\
\hline \multirow[t]{2}{*}{$0 . \mathrm{EUd} \# \Delta \mathrm{IBL}_{t}$} & & & & $0.226^{*}$ & \\
\hline & & & & $(0.119)$ & \\
\hline \multirow[t]{2}{*}{ 1.EUd\# $\Delta \mathrm{IBL}_{t}$} & & & & $1.301 * *$ & \\
\hline & & & & $(0.174)$ & \\
\hline \multirow[t]{2}{*}{$0 . \mathrm{EAd} \# \Delta \mathrm{IBL}_{t}$} & & & & & $0.363 * *$ \\
\hline & & & & & $(0.124)$ \\
\hline \multirow[t]{2}{*}{ 1.EAd\# $\Delta \mathrm{IBL}_{t}$} & & & & & $1.420 * *$ \\
\hline & & & & & $(0.213)$ \\
\hline \multirow[t]{2}{*}{$\Delta \mathrm{UNR}_{t}$} & 0.056 & -0.050 & 0.006 & 0.020 & 0.038 \\
\hline & $(0.120)$ & $(0.138)$ & $(0.058)$ & $(0.127)$ & $(0.128)$ \\
\hline \multirow[t]{2}{*}{$\Delta \mathrm{CPI}_{t}$} & -0.003 & 0.119 & $0.115^{* *}$ & -0.051 & -0.033 \\
\hline & $(0.062)$ & $(0.077)$ & $(0.037)$ & $(0.065)$ & $(0.067)$ \\
\hline \multirow[t]{2}{*}{$\Delta \mathrm{RER}_{t}$} & -0.033 & 0.051 & 0.018 & -0.034 & -0.033 \\
\hline & $(0.033)$ & $(0.034)$ & $(0.013)$ & $(0.033)$ & $(0.033)$ \\
\hline \multirow[t]{2}{*}{$\Delta \mathrm{CAC}_{t}$} & 0.037 & -0.038 & -0.002 & 0.037 & 0.043 \\
\hline & $(0.059)$ & $(0.055)$ & $(0.026)$ & $(0.061)$ & $(0.061)$ \\
\hline \multirow[t]{2}{*}{$\Delta \mathrm{PPS}_{t}$} & -0.242 & 0.853 & 0.612 & -0.385 & -0.290 \\
\hline & $(0.463)$ & $(0.561)$ & $(0.659)$ & $(0.467)$ & $(0.446)$ \\
\hline \multirow[t]{2}{*}{ Constant } & 0.058 & -0.229 & $-0.171^{*}$ & 0.217 & 0.143 \\
\hline & $(0.119)$ & $(0.165)$ & $(0.088)$ & $(0.132)$ & $(0.134)$ \\
\hline$N$ & 621 & 621 & 621 & 621 & 621 \\
\hline$R^{2}$ & 0.035 & 0.056 & 0.041 & 0.048 & 0.045 \\
\hline bic & 2717.325 & 2710.140 & 2034.501 & 2710.818 & 2712.852 \\
\hline
\end{tabular}

All variables are in first-difference. As for the explicatives of interest: $\Delta \mathrm{IBL}_{\mathrm{t}}$ is the interest bill; 0-1.EUd\# $\Delta \mathrm{IBL}_{t}$ is the interaction between the EU membership control and the interest bill; $0-1 . E A d \# \Delta \mathrm{IBL}_{t}$ is the interaction between the EA membership control and the interest bill. The remaining variables are: PBT is the cyclically-adjusted primary balance; UNR is the unemployment rate; CPI is the consumer price index; RER is the real effective exchange rate; CAC is the cyclically-adjusted primary balance; PPS is the share of population 25-49

using trend GDP, columns 7-8 use not cyclically-adjusted variables to test the robustness of our results when the GDP is included as regressor. Using variables adjusted with respect to trend GDP does not change the results at all. As for non-cyclically adjusted variables, we use log-transformed total revenues and primary expenditures; the primary budget cannot be used in this case because log-transformation of negative values is not feasible. Overall, the results on expenditure confirm MIFD, while those 
on total revenues are not reliable as expected since taxes are driven by the effect of the business cycle.

Table 8 in the appendix reports exactly the same estimations of Table 3 to which we have added year dummies. This is meant to check for common economic developments over time. The estimation output proves that the results remain unchanged in this case too. We therefore opted for a specification that does not include year dummies on the basis of parsimony considerations.

We tested also some other alternative specifications by including/excluding specific explicatives. The coefficient of on the regressor of interest, alias the interest bill, was not affected at all in any case. We therefore use the specification of the model that includes all the available regressors for ease of exposition and consistency.

\subsection{Threshold Effects}

Hansen (1999)'s threshold estimator allows to identify and test thresholds for the significance of specific controls in the regression. The estimator has been developed for non-dynamic strictly balanced panel data. We test the presence of threshold effects related to the variables: debt-to-GDP ratio (i) and the market yield of the 10 year government bond (ii). The objective is to understand whether MIFD depends on values of these variables just above a certain level.

Particularly, the estimations using the government bond yield are meant to disentangle MIFD from compliance to budget rules. In fact, assuming that budget rules are always in action, if we observe a significantly different effect when the government bond yield is higher (either in terms of level or of its volatility), we can attribute the difference to the corrective action that market pressure exerts.

The estimation output is in Table 4. Column 1 reports the estimation output based on the DGR as threshold variable. Columns 2 and 3 report the estimation output when using the government bond yield. Even though our benchmark sample is the EU27 group over the 1995-2019 period (the one used for the estimation in column 1 and in the previous Table 3), we incur in some data limitations with the government bond yield. ${ }^{16}$ Then, to gain robustness, we run two parallel estimations. The first for the EU15 block for the entire period 1995-2019 (column 2), the second for the EU27* block (Estonia excluded) for the period 2001-2019 (column 3). Column 4 reports the estimation output when using the volatility of the government bond yield over the EU27* sample, which is the larger of the two samples.

The values of the threshold are in the row "Threshold", the row "Test" reports the test of significance for the threshold itself ( $p$-value). The interest bill gets significant for an amount of the debt-to-GDP ratio above $70 \%$ (column 2). As for the government bond yield, using just the EU15 group, the estimator returns a threshold equal to $5.26 \%$ (column 2), which is a quite high value. Switching to the EU27* sample in column 3 , we obtain similar results. The estimation using the average volatility within the

\footnotetext{
16 The government bond yield is not available for the bulk of countries that accessed the EU after 2003, the so called no-EU15 block. These are mainly from central and eastern Europe and it is probably because of their transition-economy status at the beginning of the period. Apart from Estonia, data availability is from 2001.
} 


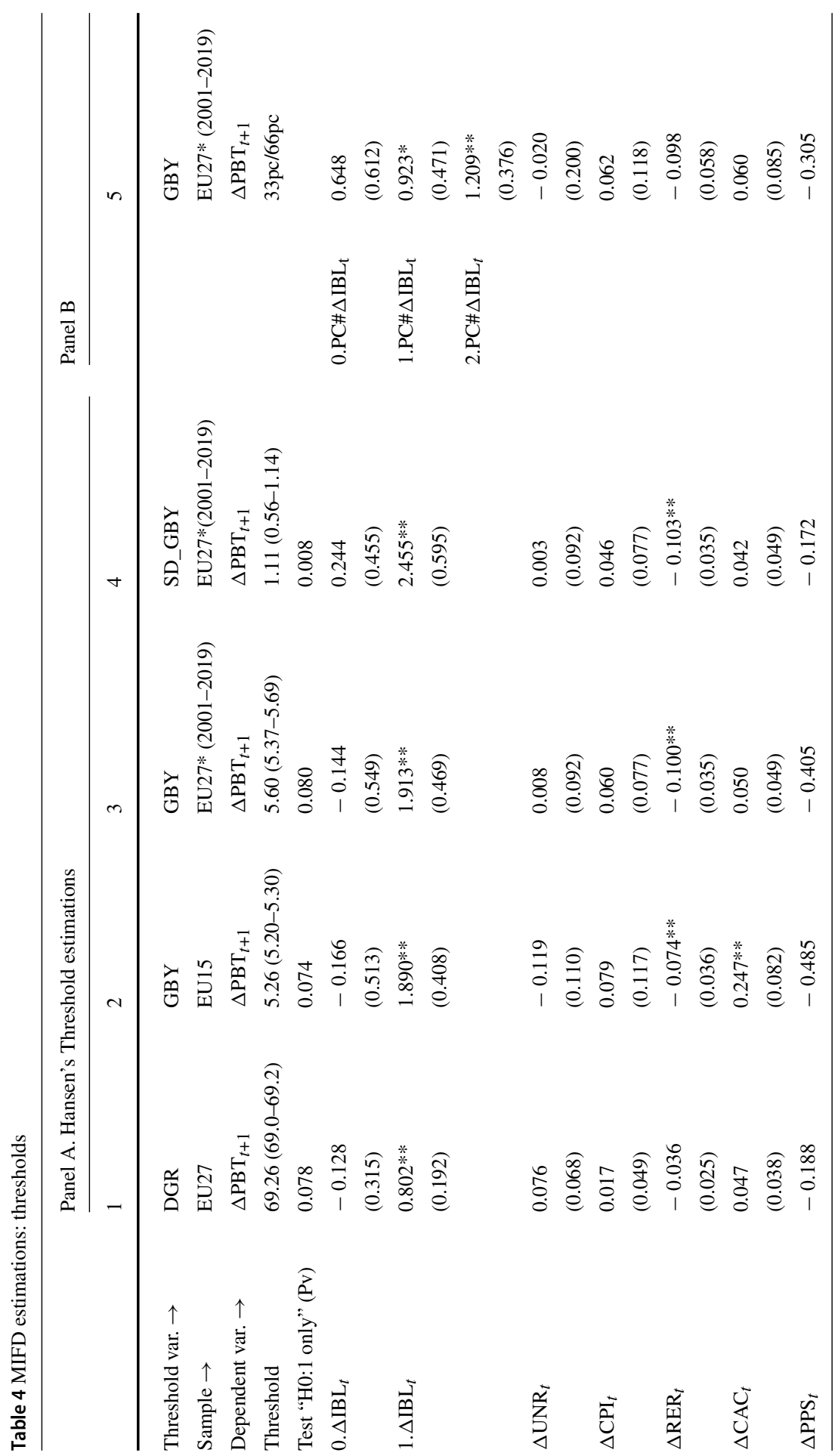




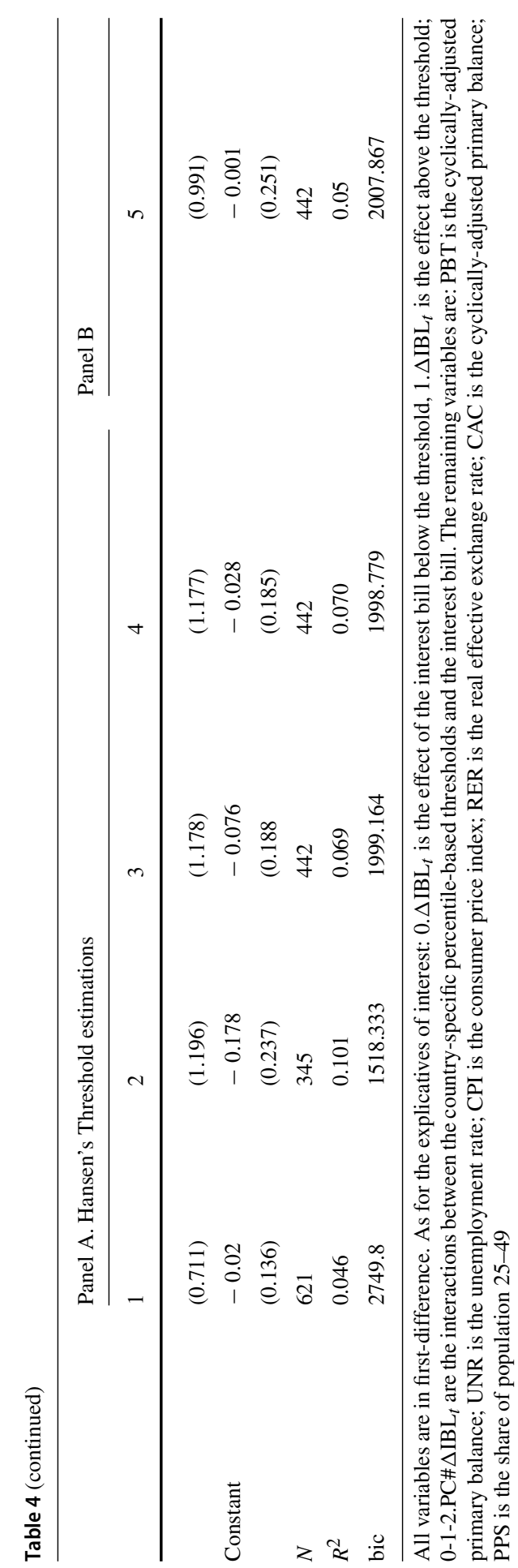


year takes to the same conclusions. The tests show that the thresholds are statistically significant and therefore the effect of the interest bill seems truly non-linear in this regard.

Hansens's estimator has the advantage to determine endogenously the threshold, but the drawback is that it is just one for all. To prove the robustness of our results, we have defined country-specific thresholds equal to the 33th and 66th percentiles of each country distribution of the government bond yield, so that we have three layers. After that we construct a dummy based on those layers and interact it with the interest bill in the usual way. The estimation output is in column 5 , it shows that the interest bill effect is increasing with market pressure. Significance emerges only for the two upper layers.

We expected thresholds linked to the amount of debt to turn out significant. Indeed, even if creditors do not consider just that in asking for risk premia, market pressure is undoubtedly more effective at higher level of the DGR. When debt gets significantly high, it is reasonable to expect the chances for fiscal authorities to intervene to increase. At the same time, it is important to have detected thresholds more directly linked to market pressure (those based on the government bond yield), alias to how market participants critically assess creditworthiness (risk premia) and price government bonds. Indeed, there are significant examples of countries that had to improve their fiscal stance under market pressure even at comparatively low levels of the debt-to-GDP ratio. Ireland at the peak of the EA debt crisis or Ukraine in 2015 are examples in this regard.

In conclusion, we point out that these results contribute to clarify that the correction we observe depends on MIFD and not on budget rules. In fact, those rules are operative regardless of market pressure, while we observe a significant effect of the interest bill just in case of high market pressure. We will get back to this point in the "Discussion of the results" subsection.

\subsection{Temporal Evolution}

As detailed in Sect. 3, there are several reasons why the commitment to MIFD might have gone through different phases over the period under consideration. Those reasons relate to the severe events that occurred in the last two decades, the main being the Global Financial Crisis. To check such possibility, we first check for a structural break. To this end, we distinguish the period preceding the global financial crisis (1995-2007, 13 years) from the following period, which has been characterized by further events more or less direct consequence of the GFC. The output of the estimation is in Table 5-Panel A. MIFD is much stronger in the post-crisis period than before.

Panel B reports the output when we estimate MIFD year-by-year, Fig. 3 plots the estimated coefficients. Considering 2007 as the breaking point, MIFD seems truly more concentrated after the GFC with the austerity years displaying a leading effect. This is likely to depend on the stronger pressure that markets exerted on sovereigns as well as on those' need to convey deeper commitment after the GFC. 


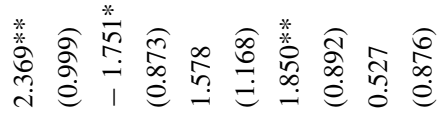

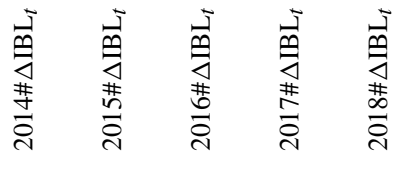

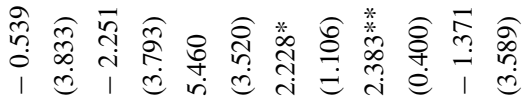

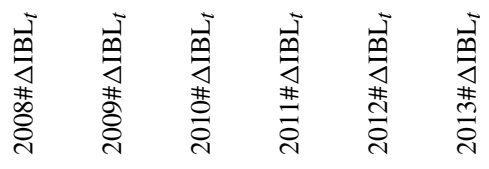

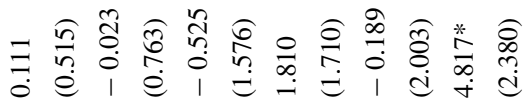

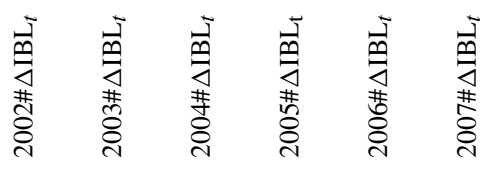

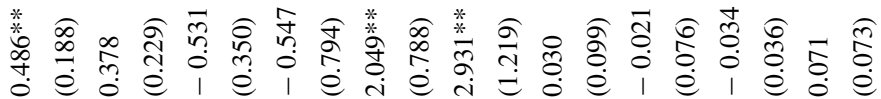

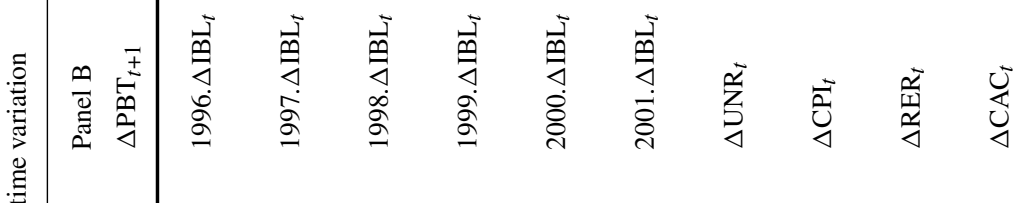

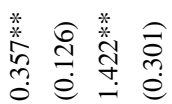

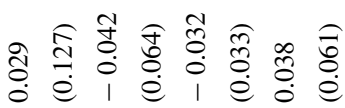

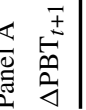

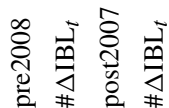

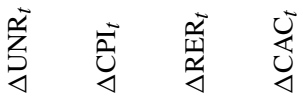




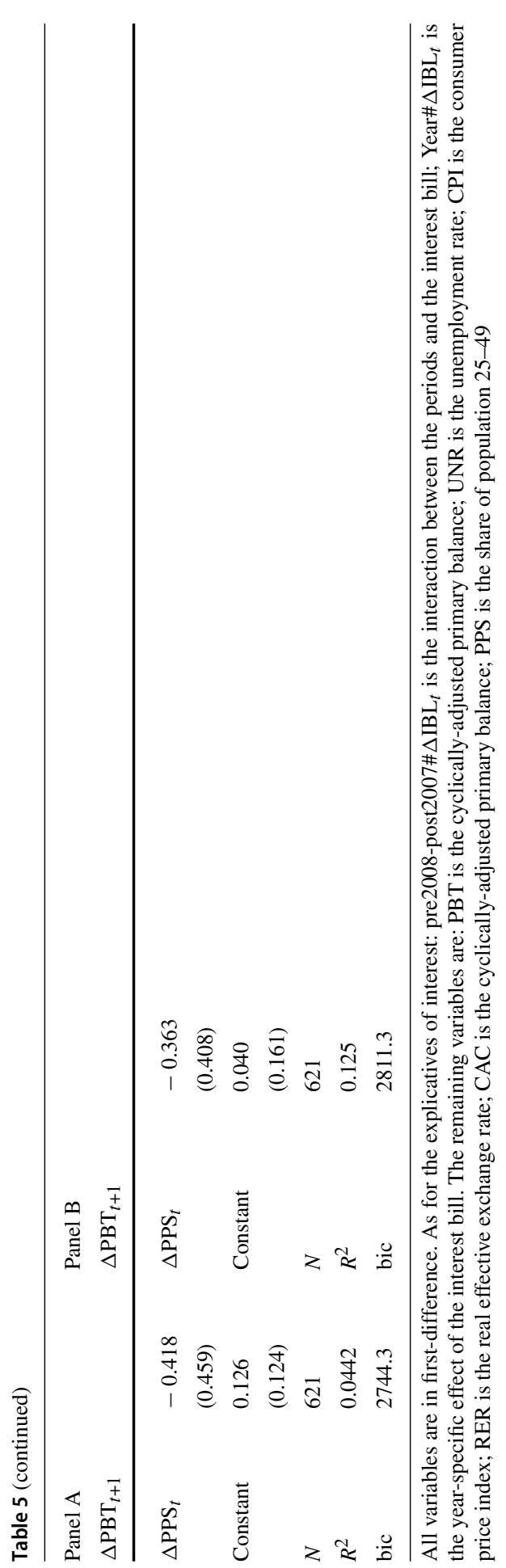




\section{MIFD effect, year-by-year}

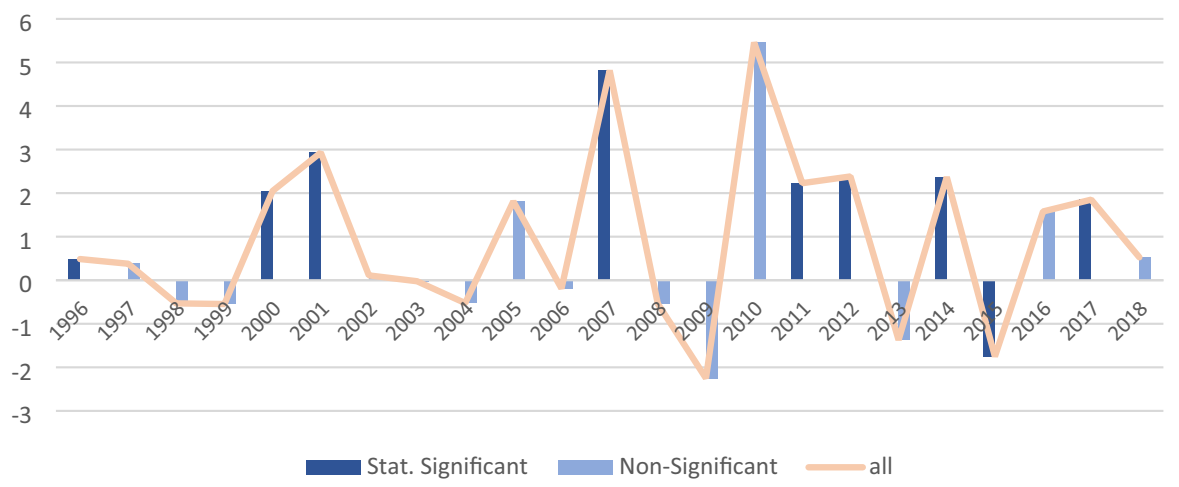

Fig. 3 MIFD year-by-year, output of the estimation in Table 5 (Panel B)

\subsection{Political Characteristics}

The last part of our analysis studies whether political aspects do play a role in the emergence of MIFD. We therefore switch the focus to some non-quantitative factors, which account for the political-economy and institutional dimension. These factors vary over time, so they may be also one of the reasons of the time evolution observed in the previous section.

In detail, we investigate whether the electoral cycle (i) as well as the election results in terms of political fragmentation (ii), size of the government majority (iii) and the political ideology of the incumbent government (iv) influence MIFD. Accordingly, Table 6 reports the estimation output of the regressions including ad-hoc controls.

Following the electoral cycle literature, the estimation in column 1 is to verify whether or not MIFD is more likely in correspondence of a recently-elected government. Theoretically, a government might decide to do soon the fiscal correction required in order to let pass as much time as possible between the consolidation and the next election. In contrast, it could opt not to pass soon unpopular measures. The estimation output shows that elections seem to undermine MIFD. To wit, following an election in $t$, governments are less likely to improve the primary budget in response to an interest bill increase.

As for the election results, column 2 reports the output of an estimation including a control for fragmented parliaments. The control takes value 1 when the parliamentary spectrum is not excessively diversified. Counterintuitively, the estimation shows that fragmentation is associated with more MIFD; this is in line with Armingeon et al. (2016)'s findings. A possible explanation is that coalition governments succeed better to consolidate the budget, while one-colour governments are less keen on taking full responsibility.

Along the same line, column 3 reports the output of an estimation including a control for governments with a large parliamentary majority. The control takes value 1 when an executive has a majority above $59.1 \%$ of the parliamentary seats available. 
Table 6 MIFD estimations: elections and political orientation

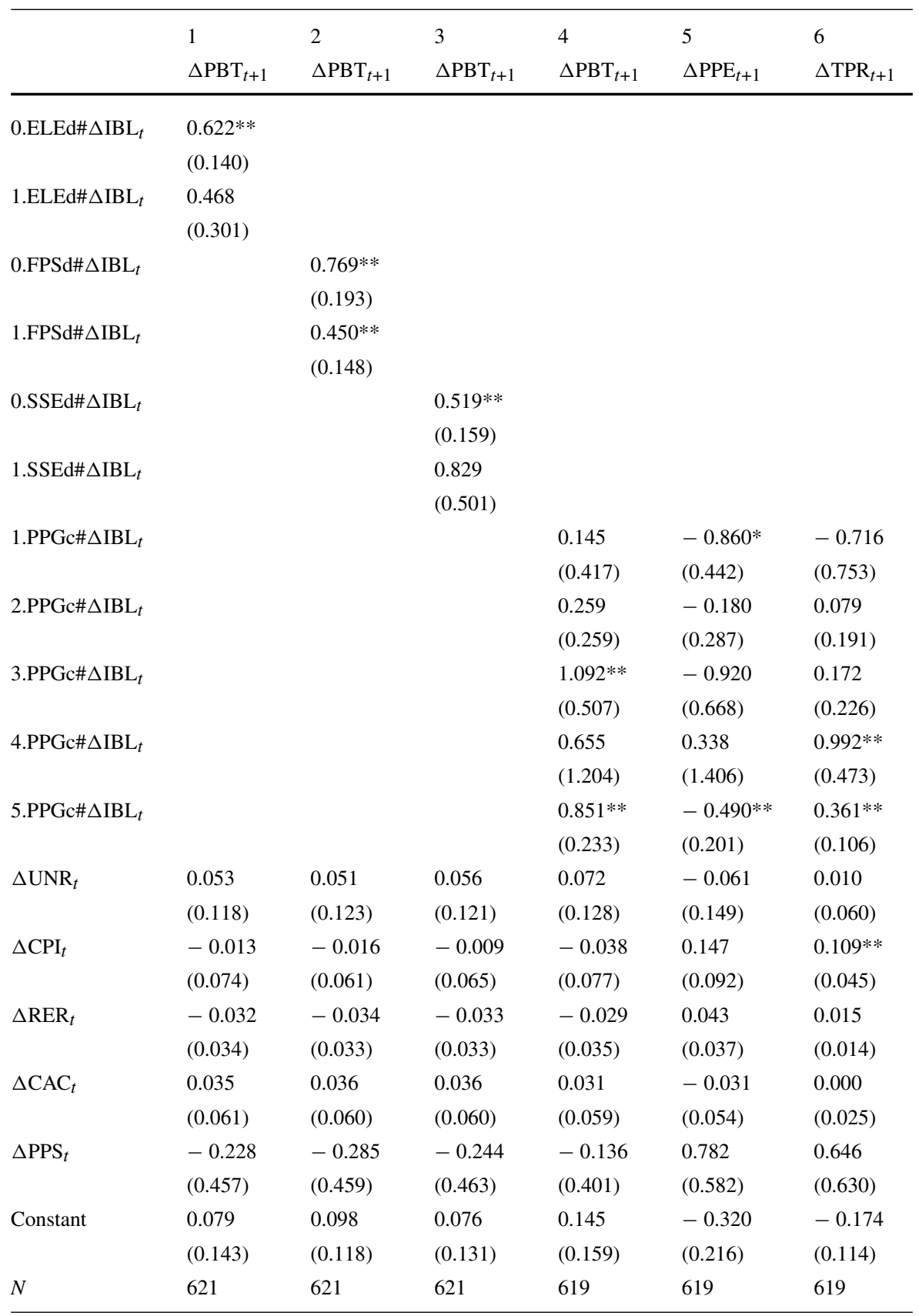


Table 6 (continued)

\begin{tabular}{lllllll}
\hline & 1 & 2 & 3 & 4 & 5 & 6 \\
& $\Delta \mathrm{PBT}_{t+1}$ & $\Delta \mathrm{PBT}_{t+1}$ & $\Delta \mathrm{PBT}_{t+1}$ & $\Delta \mathrm{PBT}_{t+1}$ & $\Delta \mathrm{PPE}_{t+1}$ & $\Delta \mathrm{TPR}_{t+1}$ \\
\hline$R^{2}$ & 0.035 & 0.036 & 0.035 & 0.042 & 0.062 & 0.064 \\
bic & 2750.117 & 2749.443 & 2749.886 & 2757.782 & 2751.308 & 2066.345 \\
\hline
\end{tabular}

All variables are in first-difference. As for the explicatives of interest: 0-1.ELEd\# $\Delta$ IBLt is the interaction between the election date control and the interest bill; 0-1.FPSd\# $\Delta \mathrm{IBL}_{t}$ is the interaction between the fragmented parliament control and the interest bill; $0-1 . S S E d \# \Delta \mathrm{IBL}_{t}$ is the interaction between the government's parliamentary majority control and the interest bill; 1-2-3-4-5.PPGc\# $\Delta$ IBLt is the interaction between the interest bill and the control for government's political orientation. The remaining variables are: PBT is the cyclically-adjusted primary balance; UNR is the unemployment rate; CPI is the consumer price index; RER is the real effective exchange rate; CAC is the cyclically-adjusted primary balance; PPS is the share of population $25-49$

To notice that such a large majority in terms of seats might be of many small parties or just a few. The estimation shows that strong executives theoretically realize larger consolidations, however, the effect does not seem statistically significant.

When we look at the political ideology of the government, the estimation output in column 4 uses a categorical variable for different compositions of the government. It takes value 1 when there is hegemony of right/centre parties, 2 for dominance of right/centre parties, 3 for balance of power between left and right, 4 dominance of left parties, 5 for hegemony of left parties. The estimation output suggests that particularly politically-balanced cabinets, as well as left-dominated cabinets, increase the chances for MIFD at the EU27 level. Following Potrafke (2020), we replace the dependent variable with primary expenditures and total revenues to understand better this result. A possible naïve expectation is that expenditure-based consolidations are more associated with rightist parties, while tax-based consolidations are to leftish parties. Nicely, the estimation in column 5 suggests that rightist governments act significantly through a reduction of expenditure, as do leftish governments but at a far lower extent; this is in line with Hübscher (2016)'s findings. Differently, rightist governments do not seem to act at all on the revenues side, while centre-left governments seem to do.

\subsection{Discussion of the Results}

The evidence we collect from the estimations presented in the previous sections, jointly considered, clarifies that markets exert a significative corrective action on the fiscal stance. This conclusion is coherent with the findings in Larch and Santacroce (2020).

Threshold estimations, in particular, show that market pressure (as quantified by higher yields as well as volatility) is crucial for MIFD as it is reasonable to expect. For low levels of such variables, no significant effect of the interest bill is detectable. Nicely, it emerges also that gradual increases of the yield are accompanied by progressively stronger MIFD, which is a sensible result. These results are coherent with those about the temporal evolution of the effect of the interest bill. In fact, crisis and post-crisis years return larger effects. 
On the whole, we believe that such an evidence, obtained through different approaches, rules out the possibility that what we capture is compliance to budget rules instead of MIFD. More specifically, as for rules related to the deficit or to the structural-balanced budget, simple correlations between the variation of the interest bill and the variation of the cyclically-adjusted primary balance are very low (Table 2). Then, these variables reflect different dynamics. Consequently, one cannot affirm that the effect we detect is compliance to the deficit/SBB rules. In that case, since the objective of the rule is not the interest bill, we should have observed at least a high correlation between the object of the rule and the interest bill.

As for compliance to debt rules, those are expressed in terms of the level of the debt stock, not in terms of evolution of the interest bill. Of course, the two are linked. Formally, the rule implies that a today variation of the debt level (if above the limit) should cause a reduction of the primary balance to contrast the evolution of the debt stock. Theoretically, since the variation of the interest bill is correlated with the variation of the debt stock, the effect of the interest bill that we detect might also capture compliance to the debt rule. Even though we cannot exclude this a priori, our results exclude the probability of such an outcome. The threshold estimations specifically show a significant effect only when market pressure is high. This clearly indicates that the action of markets is crucial and makes a difference regarding a significant effect of the interest bill on the budget stance. Furthermore, the estimation with the EU control in Table 3 aims to exploit the different accession date of member countries. Even if it has limitations, it is informative and provides support to the conclusion that MIFD occurs also when the EU rules do not apply.

Larch and Santacroce (2020) discuss compliance to EU budget rules by constructing a dataset that check the evolution of budget variables against the one required to respect budget rules. They conclude that "following the rules is as common as not following them" and that "compliance with rules aimed to correct for the cycle is just procyclical". They also control for the effect of market pressure in a parallel exercise and arrive to the same conclusion as we do: "government react to heightened concerns of investors by controlling debt".

All that said, we conclude that our results are clear about the emergence of marketinduced fiscal discipline.

\section{Conclusions}

Public debt is at the centre of the economic and political debate, its amount conditions economic policy whenever threats to its sustainability materialize, or when budget equilibrium is an economic-policy objective. In the introduction to this work, we have explained that financial markets may play a role in a country's fiscal stance. The objective of our research was to investigate whether such a role emerges in the EU over the last three decades and to prove that market-induced fiscal discipline is driven by some factors; such as euro-area membership, the policy response to crises, etc.

On the whole, we have found evidence of a positive effect of the interest bill on the primary budget, which materializes mainly on the expenditure side. Membership in the EU and the euro area seems to strengthen fiscal discipline, but it emerges in 
the EU27 group of countries anyway. Such an effect is proved to depend on the level of some key variables, such as the debt-to-GDP ratio and the market yield. Both are fundamental determinants of sustainability and provide different perspectives. Indeed, even countries with a low debt-to-GDP ratio, such as Ireland, were forced to correct their fiscal stance in response to market pressure. The financial crises included in the period of investigation suggest that countries have been more committed to fiscal discipline during periods of turmoil and recession, alias after 2007.

Elections do not seem to drive fiscal discipline. This is likely to suggest that, when they are necessary, fiscal corrections dissolve political parties' selfish strategies. Interestingly, fragmentation is associated with fiscal discipline. We believe that this signals that coalition governments are keener on fiscal consolidation. Probably because they are more suited to enforce consolidation plans in some countries, or because they allow to share the cost in terms of voters' support. As for the political orientation, particularly politically-balanced cabinets, as well as left-dominated cabinets, increase the chances for fiscal discipline at the EU27 level. Furthermore, rightist governments act significantly through a reduction of expenditure, as do leftish governments but to a lower extent.

Funding Open access funding provided by Università degli Studi di Catania within the CRUI-CARE Agreement.

Open Access This article is licensed under a Creative Commons Attribution 4.0 International License, which permits use, sharing, adaptation, distribution and reproduction in any medium or format, as long as you give appropriate credit to the original author(s) and the source, provide a link to the Creative Commons licence, and indicate if changes were made. The images or other third party material in this article are included in the article's Creative Commons licence, unless indicated otherwise in a credit line to the material. If material is not included in the article's Creative Commons licence and your intended use is not permitted by statutory regulation or exceeds the permitted use, you will need to obtain permission directly from the copyright holder. To view a copy of this licence, visit http://creativecommons.org/licenses/ by $/ 4.0 /$.

\section{Appendix: Tables and Charts}

See Tables 7 and 8; Figs. 4, 5 and 6. 


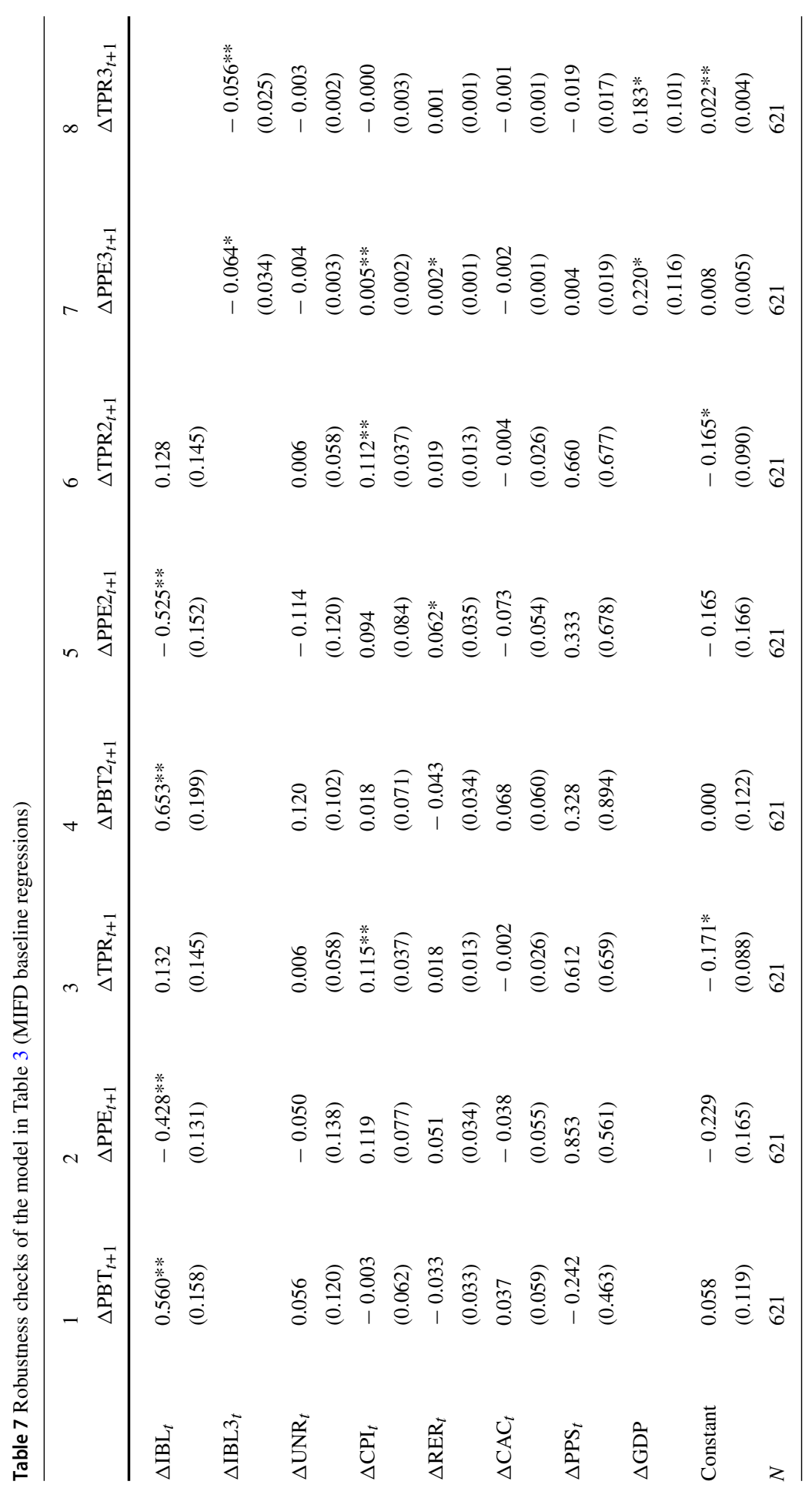




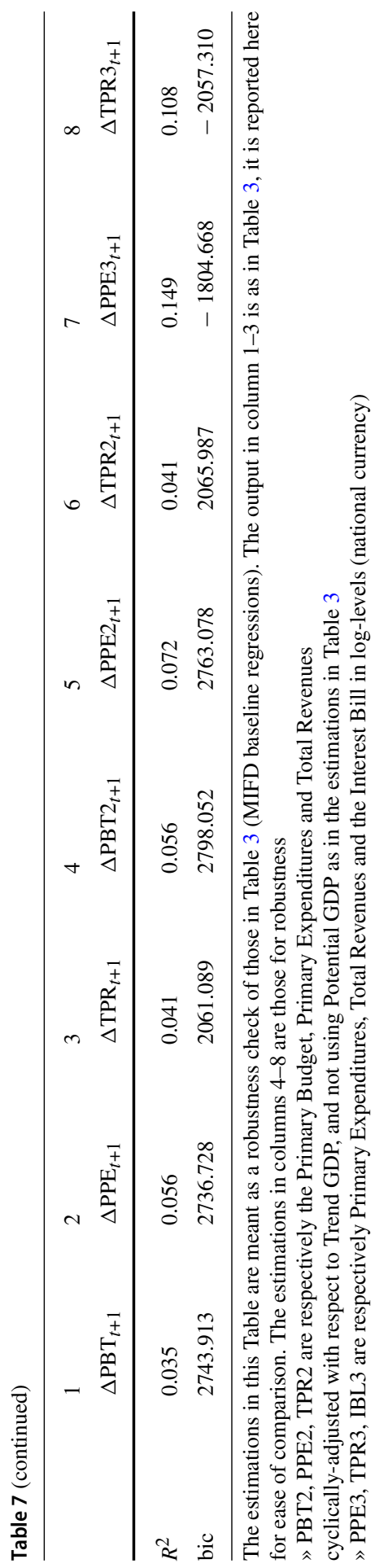


Table 8 Robustness checks of the model in Table 3 (MIFD baseline regressions): year dummies added

\begin{tabular}{|c|c|c|c|c|c|}
\hline & (1) & (2) & (3) & (4) & (5) \\
\hline & $\Delta \mathrm{PBT}_{t+1}$ & $\Delta \mathrm{PPE}_{t+1}$ & $\Delta \mathrm{TPR}_{t+1}$ & $\Delta \mathrm{PBT}_{t+1}$ & $\Delta \mathrm{PBT}_{t+1}$ \\
\hline \multirow[t]{2}{*}{$\Delta \mathrm{IBL}_{t}$} & $0.634 * *$ & $-0.469 * *$ & 0.165 & & \\
\hline & $(0.156)$ & $(0.170)$ & $(0.138)$ & & \\
\hline \multirow[t]{2}{*}{$0 . \mathrm{EUd} \# \Delta \mathrm{IBL} t$} & & & & $0.347 * *$ & \\
\hline & & & & $(0.148)$ & \\
\hline \multirow[t]{2}{*}{ 1.EUd\# $\Delta \mathrm{IBL}_{t}$} & & & & $1.289 * *$ & \\
\hline & & & & $(0.175)$ & \\
\hline \multirow[t]{2}{*}{$0 . \mathrm{EAd} \# \Delta \mathrm{IBL}_{t}$} & & & & & $0.490^{* *}$ \\
\hline & & & & & $(0.123)$ \\
\hline \multirow[t]{2}{*}{ 1.EAd\# $\Delta \mathrm{IBL}_{t}$} & & & & & $1.334 * *$ \\
\hline & & & & & $(0.241)$ \\
\hline \multirow[t]{2}{*}{$\Delta \mathrm{UNR}_{t}$} & -0.003 & -0.012 & -0.016 & -0.030 & -0.019 \\
\hline & $(0.125)$ & $(0.149)$ & $(0.051)$ & $(0.127)$ & $(0.129)$ \\
\hline \multirow[t]{2}{*}{$\Delta \mathrm{CPI}_{t}$} & 0.037 & 0.108 & $0.145^{* *}$ & -0.014 & 0.019 \\
\hline & $(0.078)$ & $(0.102)$ & $(0.040)$ & $(0.079)$ & $(0.078)$ \\
\hline \multirow[t]{2}{*}{$\Delta \mathrm{RER}_{t}$} & -0.008 & 0.024 & 0.017 & -0.009 & -0.008 \\
\hline & $(0.026)$ & $(0.031)$ & $(0.014)$ & $(0.025)$ & $(0.026)$ \\
\hline \multirow[t]{2}{*}{$\Delta \mathrm{CAC}_{t}$} & 0.056 & -0.062 & -0.006 & 0.058 & 0.061 \\
\hline & $(0.067)$ & $(0.059)$ & $(0.029)$ & $(0.068)$ & $(0.068)$ \\
\hline \multirow[t]{2}{*}{$\Delta \mathrm{PPS}_{t}$} & -0.008 & 0.493 & 0.485 & 0.120 & -0.013 \\
\hline & $(0.659)$ & $(0.660)$ & $(0.764)$ & $(0.601)$ & $(0.623)$ \\
\hline \multirow[t]{2}{*}{ Constant } & -0.068 & -0.293 & -0.361 & 0.251 & 0.014 \\
\hline & $(0.357)$ & $(0.434)$ & $(0.269)$ & $(0.350)$ & $(0.353)$ \\
\hline$N$ & 621 & 621 & 621 & 621 & 621 \\
\hline$R^{2}$ & 0.105 & 0.104 & 0.121 & 0.114 & 0.111 \\
\hline bic & 2825.590 & 2832.855 & 2135.927 & 2819.343 & 2821.517 \\
\hline
\end{tabular}



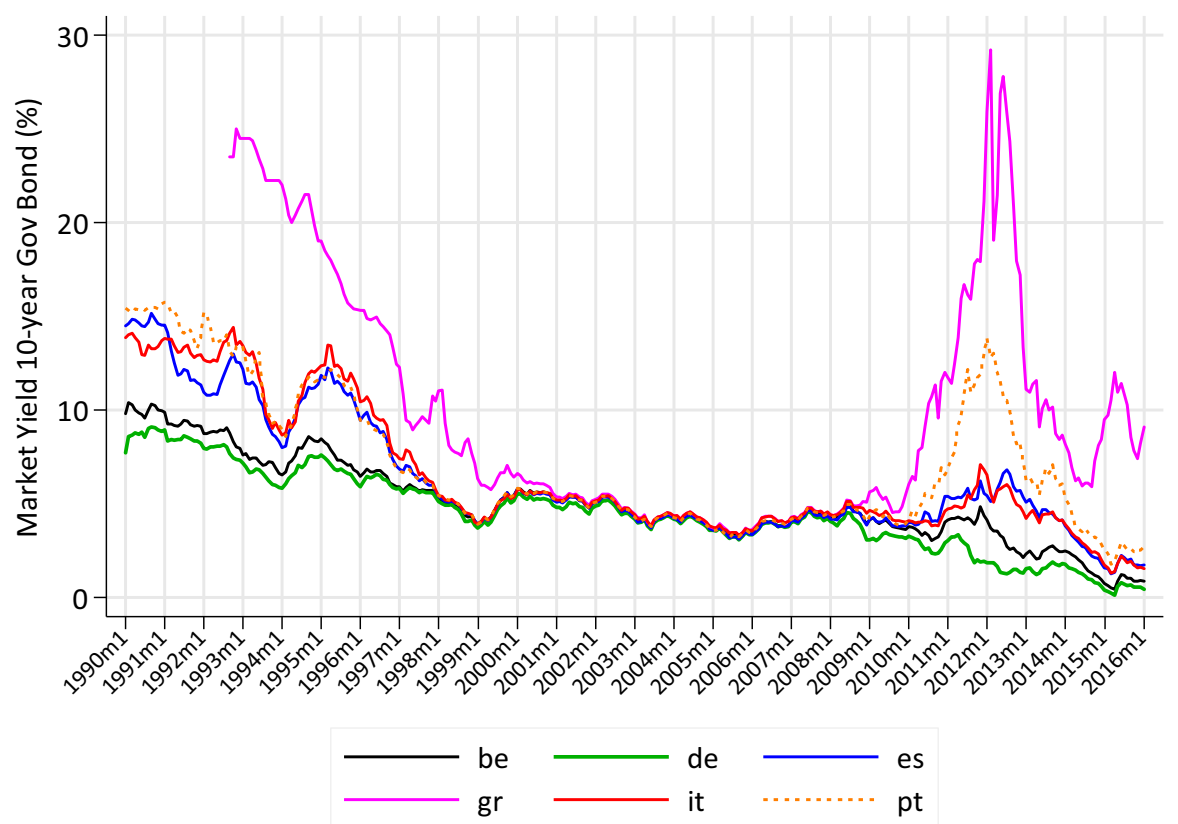

Fig. 4 Market Yield of the 10-year benchmark bond (GBY)
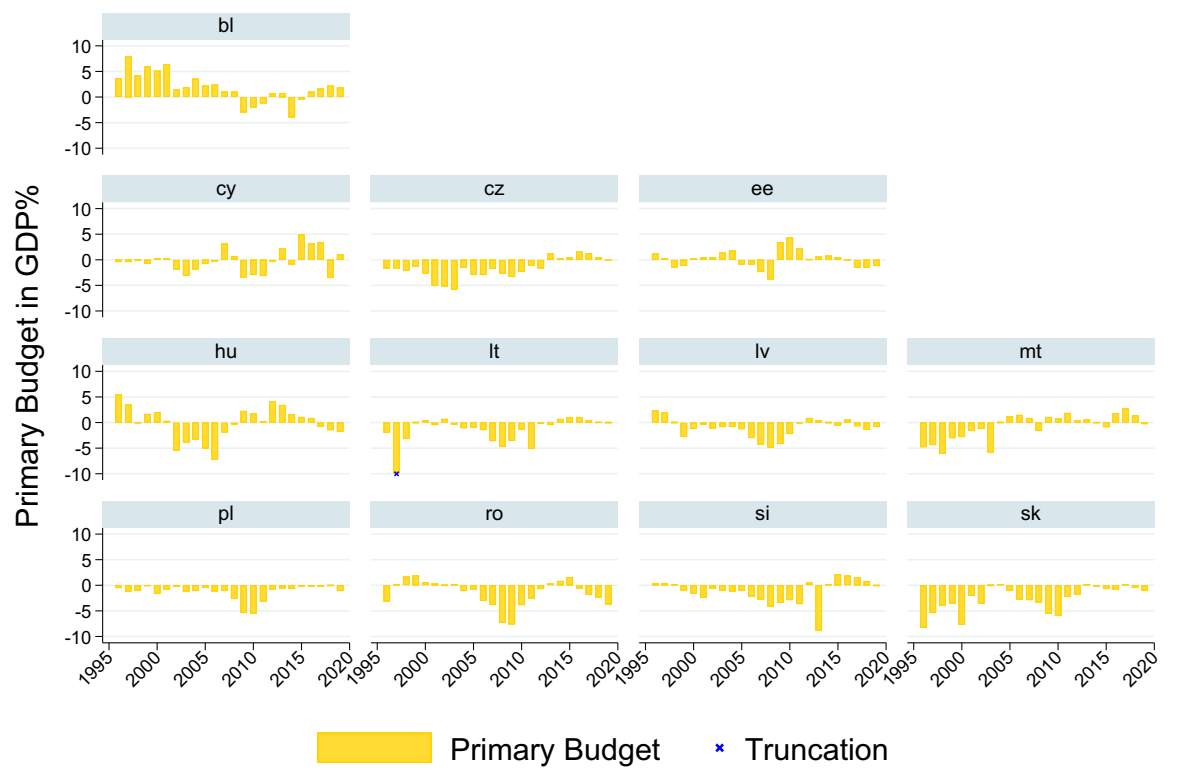

Fig. 5 Primary Budget in GDP terms, no-EU15 group 

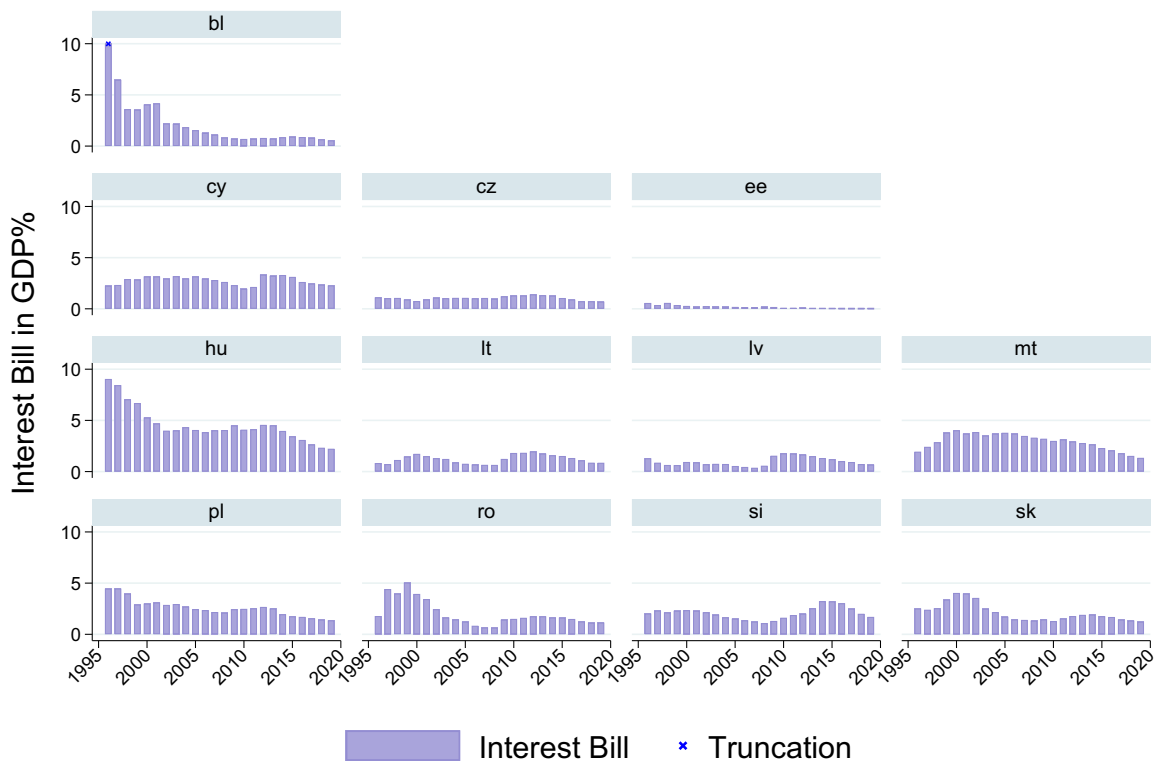

Fig. 6 Interest Bill in GDP terms, no-EU15 group

\section{References}

Agnello L, Sousa R (2014) How does fiscal consolidation impact on income inequality? Rev Income Wealth 60(4):702-726

Agnello L, Fazio G, Sousa RM (2016) National fiscal consolidations and regional inequality in Europe. Cambridge J Regions Econ Soc 9:59

Agnello L, Castro V, Jalles JT, Sousa RM (2017) Income inequality, fiscal stimuli and political (in)stability. Int Tax Public Financ 24:484-511

Alesina A, Ardagna S (2010) Large changes in fiscal policy: taxes versus spending. Tax Policy Econ 24:35-68

Alesina A, Roubini N (1992) Political cycles in OECD economies. Rev Econ Stud 59:663-688

Armingeon K, Guthmann K, Weisstanner D (2016) Choosing the path of austerity: how parties and policy coalitions influence welfare state retrenchment in periods of fiscal consolidation. West Eur Polit 39:628-647

Armingeon Ket al (2020) Comparative political data set 1960-2018. Institute of Political Science, University of Zurich, Zurich

Bamba M, Combes J-L, Minea A (2020) The effects of fiscal consolidations on the composition of government spending. Appl Econ 52:1517-1532

Barro RJ (1990) Government spending in a simple model of endogeneous growth. J Polit Econ 98:S103-S125

Bartolini D, Sacchi A, Salotti S, Santolini R (2017) Fiscal decentralization in times of financial crises. Cesifo Econ Stud 64(3):456-488

Bayoumi T, Goldstein M, Woglom G (1995) Do credit markets discipline sovereign borrowers? Evidence from US states. J Money Credit Bank 27:1046-1059

Bishop G, Damrau D, Miller M (1989) Market discipline can work in the EC Monetary Union. Salomon Bros

Bojar A (2019) With a little help from my friends: ministerial alignment and public spending composition in parliamentary democracies. Polit Res Exch 1:1-21

Brunet J, Pàrraga S (2021) Fiscal rebalancing plans in the medium term: the case of the United Kingdom. Economic Bulletin 2/2021, Banco de Espana 
Cafiso G (2012) Debt developments and fiscal adjustment in the EU. Intereconomics 47(1):61-72

Cafiso G (2016) Non-residents holdings, market volatility and public debt sustainability. An analysis with data for Italy. Rev Int Econ 24:484-513

Cafiso G, Cellini R (2014) Fiscal consolidations and public debt in Europe. Int Tax Public Financ 21:614-644

Caporin M, Pelizzon L, Ravazzolo F, Rigobon R (2018) Measuring sovereign contagion in Europe. J Financ Stab 34:150-181

De Haan J, Sturm J-E (2000) Do financial markets and the Maastricht Treaty discipline governments? New evidence. Appl Financ Econ 10:221-226

De Groot O, Holm-Hadulla F, Leiner-Killinger N (2015) Cost of borrowing shocks and fiscal adjustment. J Int Money Financ 59:23-48

Dell'Erba S, Mattina T, Roitman A (2015) Pressure or prudence? Tales of market pressure and fiscal adjustment. J Int Money Financ 51:196-213

Fedelino A, Ivanova A, Horton M (2009) Computing cyclically adjusted balances and automatic stabilizers. International Monetary Fund

Giordano R, Momigliano S, Neri S, Perotti R (2007) The effects of fiscal policy in Italy: evidence from a VAR model. Eur J Polit Econ 23(3):707-733

Hansen BE (1999) Threshold effects in non-dynamic panels: estimation, testing, and inference. J Econ 93:345-368

Heinemann F, Winschel V (2001) Public deficits and borrowing costs: the missing half of market discipline. J Public Financ Public Choice 19:169-190

Hicks AM, Swank DH (1992) Politics, institutions, and welfare spending in industrialized democracies, 1960-82. Am Polit Sci Rev 86:658-674

Hübscher E (2016) The politics of fiscal consolidation revisited. J Publ Policy 36:573-601

Korner FM, Zemanek H (2013) On the Brink? Intra-euro area imbalances and the sustainability of foreign debt. Rev Int Econ 21(1):18-34

Larch M, Santacroce S (2020) Numerical compliance with EU fiscal rules: the compliance database of the Secretariat of the European Fiscal Board. European Fiscal Board

Mierau JO, Jong-A-Pin R, De Haan J (2007) Do political variables affect fiscal policy adjustment decisions? New empirical evidence. Public Choice 133:297-319

Panizza U, Presbitero AF (2013) Public debt and economic growth in advanced economies: a survey. Swiss J Econ Stat 149:175-204

Panizza U, Presbitero AF (2014) Public debt and economic growth: is there a causal effect? J Macroecon 41:21-41

Perotti R (2013) The "Austerity Myth": Gain without Pain?. In: A. Alesina \& F. Giavazzi, eds. s.1.:NBER

Potrafke N (2017) Partisan politics: the empirical evidence from OECD panel studies. J Comp Econ 45:712-750

Potrafke N (2020) General or central government? Empirical evidence on political cycles in budget composition using new data for OECD countries. Eur J Polit Econ 63:101860

Presbitero AF, Sacchi A, Zazzaro A (2014) Property tax and fiscal discipline in OECD countries. Econ Lett $124: 428-433$

Romer CD, Romer DH (2010) The macroeconomic effects of tax changes: estimates based on a new measure of fiscal shocks. Am Econ Rev 100:763

Tkačevs O, Vilerts K (2019) The impact of government borrowing costs on fiscal discipline. Kyklos 72:446-471

Publisher's Note Springer Nature remains neutral with regard to jurisdictional claims in published maps and institutional affiliations. 